\title{
23. MICROFOSSILS IN THIN SECTIONS FROM THE MESOZOIC DEPOSITS OF LEG 11, DEEP SEA DRILLING PROJECT
}

\author{
Roger Lehmann, Esso Production Research-European, 33-Bégles (France)
}

Seventy-six thin sections from late Jurassic and early Cretaceous deposits recovered at Sites 99, 100, 101, and 105 in the western North Atlantic during Leg 11 of the Deep Sea Drilling Project were examined for their content of microfossils. The thin sections were placed at my disposal by H. P. Luterbacher.

Most of the samples consist of relatively soft, chalky limestones which had to be impregnated with Araldit before cutting and grinding. Although the technicians handled the samples with great care and experience, it was often not possible to obtain thin sections of satisfactory quality.

The microfossil content of the thin sections from the Upper Jurassic and Lower Cretaceous penetrated during Leg 11 is disappointingly poor compared to age-equivalent deposits in similar facies from the Alpine-Mediterranean area. It is therefore not necessary to give a detailed account of each thin section. Only a few important samples will be mentioned specifically. The results of the examination of the thin sections have to be combined with the evidence from the washed residues and other groups of fossils in order to establish the stratigraphic succession penetrated at each site (see Site Reports, Chapters 1 through 9, this volume).

A few characteristic microfossils are illustrated on Plate 1.

\section{SITE 99}

Samples:

99A-3, core catcher

$99 \mathrm{~A}-9$, core catcher

Both thin sections contain only nannoconids and radiolarians of probably early Cretaceous age.

\section{SITE 100}

Samples:

$100-1-4,108-110 \mathrm{~cm}$

$100-1$, core catcher

$100-2-2,50-52 \mathrm{~cm}$

$100-2-2,71-74 \mathrm{~cm}$
100-2, core catcher $100-5-2,110-112 \mathrm{~cm}$ $100-6$, core catcher $100-7-1,42-44 \mathrm{~cm}$
The two samples from Core 100-1 contain only radiolarians.

The three samples from Core 100-2 are rich in Saccocoma sp. and sections through aptychi. In the Alpine-Mediterranean area, beds with abundant Saccocoma sp. are generally attributed to the Kimmeridgian.

The thin sections from Cores 100-5, 6, and 7 have only radiolarians, sponge spicules and sections through aptychi.

\section{SITE 101}

Samples:

$$
\begin{aligned}
& \text { 101A-4, core catcher } \\
& 101 \mathrm{~A}-7-1,148-150 \mathrm{~cm} \\
& 101 \mathrm{~A}-8-1,0-2 \mathrm{~cm} \\
& 101 \mathrm{~A}-8-1,34-36 \mathrm{~cm} \\
& 101 \mathrm{~A}-9-1,65-67 \mathrm{~cm}
\end{aligned}
$$$$
\begin{aligned}
& \text { 101A-9-1, 125-127 cm } \\
& 101 \mathrm{~A}-9, \text { core catcher } \\
& 101 \mathrm{~A}-10-1,73-75 \mathrm{~cm} \\
& 101 \mathrm{~A}-10-1,83-85 \mathrm{~cm} \\
& 101 \mathrm{~A}-10, \text { core catcher }
\end{aligned}
$$

The thin sections from Cores 101A-4 and 101A-8 are void of microfossils. All the other samples contain radiolarians and questionable tintinnids. They are probably of early Cretaceous age.

\section{SITE 105}

\section{Samples:}

$$
\begin{aligned}
& 105-18-5,94-96 \mathrm{~cm} \\
& 105-18-6,132-134 \mathrm{~cm} \\
& 105-19-2,52-54 \mathrm{~cm} \\
& 105-19-3,42-43 \mathrm{~cm} \\
& 105-19, \text { core catcher } \\
& 105-20-1,80-82 \mathrm{~cm} \\
& 105-20-1,174-176 \mathrm{~cm} \\
& 105-20, \text { core catcher } \\
& 105-21-1,58-60 \mathrm{~cm} \\
& 105-21-1,108-110 \mathrm{~cm} \\
& 105-22-1,144-146 \mathrm{~cm} \\
& 105-22-2,59-61 \mathrm{~cm} \\
& 105-22-2,134-136 \mathrm{~cm} \\
& 105-23-1,103-105 \mathrm{~cm} \\
& 105-23-2,15-17 \mathrm{~cm} \\
& 105-23-2,65-67 \mathrm{~cm} \\
& 105-24-1,58-61 \mathrm{~cm} \\
& 105-24-1,92-94 \mathrm{~cm}
\end{aligned}
$$

$105-28-3,28-30 \mathrm{~cm}$ $105-28-3,100-102 \mathrm{~cm}$ $105-28-4,60-62 \mathrm{~cm}$ $105-28-5,30-32 \mathrm{~cm}$ $105-28-5,139-141 \mathrm{~cm}$ 105-28-6, 90-92 cm 105-28, core catcher $105-29-1,100-102 \mathrm{~cm}$ $105-29-2,124-126 \mathrm{~cm}$ $105-29-3,3-5 \mathrm{~cm}$ 105-29, core catcher $105-30-1,129-131 \mathrm{~cm}$ 105-30-2, $124-126 \mathrm{~cm}$ 105-30, core catcher 105-31-2, 89-91 cm 105-31, core catcher $105-32-2,116-118 \mathrm{~cm}$ $105-32-2,26-28 \mathrm{~cm}$ 


$$
\begin{array}{ll}
105-25-1,24-26 \mathrm{~cm} & 105-32, \text { core catcher } \\
105-25-3,19-22 \mathrm{~cm} & 105-33-1,12-14 \mathrm{~cm} \\
105-26-1,12-14 \mathrm{~cm} & 105-33-1,42-43 \mathrm{~cm} \\
105-26-2,142-144 \mathrm{~cm} & 105-33-1,94-96 \mathrm{~cm} \\
105-27-1,2-4 \mathrm{~cm} & 105-34-2,133-134 \mathrm{~cm} \\
105-27-2,2-4 \mathrm{~cm} & 105-34-3,15-16 \mathrm{~cm} \\
105-27-3,14-16 \mathrm{~cm} & 105-34-5,112-113 \mathrm{~cm} \\
105-27-3,67-69 \mathrm{~cm} & 105-35-2,30-32 \mathrm{~cm} \\
105-28-2,52-54 \mathrm{~cm} & 105-36-2,100-102 \mathrm{~cm} \\
105-28-2,142-144 \mathrm{~cm} &
\end{array}
$$

All thin sections from the interval of Cores 105-18 to 105-32 contain radiolarians and questionable, generally recrystallized tintinnids, which cannot be determined specifically (Plate 1, Figures 11 and 12). These problematic tintinnids are often of a very small size. They are probably detected much more easily in smear slides and under magnifications used for the study of calcareous nannoplankton, rather than in thin sections and under magnifications normally used for the study of tintinnids.

From Core 105-25 to Core 105-36, Stomiosphaera-like organisms are always present. Stomiosphaera are small spheres (diameter 30 to 60 microns) of unknown systematic position. Some authors assign them to the tintinnids. They are known from the Tithonian and Neocomian open-marine limestones of the Tethys.

The first nannoconids are observed in Core 105-26 and are found in abundance down to Core 105-33. Sections through aptychi, sponge spicules, and prisms of Inoceramus (?) occur scattered through the same interval.

The only tintinnids which could be determined specifically are found in Sample 105-33-1, 42 to 43 centimeters. The most common species is Calpionella alpina Lorenz (Plate 1, Figure 1 through 6). A few forms are determined as Tintinnopsella carpathica (Murgeanu and Filipescu), small variety of J. Remane (in Hégarat and Remane, 1968) (Plate 1, Figures 7 through 10). The coexistence of these two species indicates that this sample has to be placed in the vicinity of the Jurassic-Cretaceous boundary. Since this sample still contains abundant nannoconids, I prefer to place it in the basal Cretaceous (early Berriasian).
However, an attribution to the topmost Tithonian cannot be excluded. Only nannoconids are found in the underlying sample (105-33-1, 94 to 96 centimeters).

Core 105-34 contains numerous sections of Saccocoma sp. (Plate 1, Figures 17 and 18) and is therefore probably of Kimmeridgian age. In addition, sections through aptychi, debris of echinoderms and bivalves, and a few radiolarians are observed in the thin sections from Cores 105-34, 35, and 36.

\section{REFERENCES}

Bouché, P.M., 1965. Etat des connaissances sur les nannofossiles calcaires du Crétacé inférieur. Bur. Recherches Géol. Minières Mém. no. 34 (Colloque sur le Crétacé inférieur, Lyon 1963), 451.

Brönnimann, P., 1955. Microfossils incertae sedis from the Upper Jurassic and Lower Cretaceous of Cuba. Micropaleontology, 1 (1), 28.

Colom, G., 1955. Jurassic-Cretaceous sediments of the western Mediterranean zone and the Atlantic area. Micropaleontology, 1 (2), 109.

Kristan-Tollmann, E., 1962. Stratigraphisch wertvolle Mikrofossilien aus dem Oberjura und Neokom der nördlichen Kalkalpen. Erdoel Z., Heft 11, 637.

Le Hégarat, G. and Remane J., 1968. Tithonique supérieur et Berriasien de la bordure cévenole. Corrélation des Ammonites et des Calpionelles. Geobios (Fac.Sci.Lyon), no. 1, 7.

Noël, D., 1965. Sur les coccolithes du Jurassique europeen et d'Afrique du Nord. Essai de classification des coccolithes fossiles. Ed. Cent. Nat. Recherches Scientifiques, Paris, 206p.

Stradner, H., 1963. New contributions to Mesozoic stratigraphy by means of nannofossils. Proc. $6^{\text {th }}$ World Petrol. Cong. Section 1, 167.

Verniory, R., 1954. Eothrix alpina Lombard, algue ou crinoide? Archives Sci. Geneve. 7, fasc. 4, 327 

PLATE 1.

Microfossils from the Upper Jurassic and Lower Cretaceous of Site 105.

Figures 1-6 Calpionella alpina Lorenz; Sample 105-33-1, 42-43 $\mathrm{cm}$; latest Jurassic to earliest Cretaceous; $\times 400$.

Figures 7-10 Tintinnopsella carpathica (Murgeanu and Filipescu), small variety J. Remane (1968); Sample 105-33-1, 42-43 cm; latest Jurassic to earliest Cretaceous; $\times 400$.

Figure 11 Questionable recrystallized tintinnid; Sample 10529-1, 100-102 cm; early Cretaceous (?); X400.

Figure 12 Questionable recrystallized tintinnid; Sample 105$31-2,80-91 \mathrm{~cm}$; basal Cretaceous (?); X200.

Figures 13,14 Nannoconids; Sample 105-32, core catcher; basal Cretaceous (?); $\times 800$.

Figures 15,16 Nannoconids; Sample 105-33-1, 12-14 cm; basal Cretaceous (?); $\times 800$.

Figures 17,18 Saccocoma sp.; Sample 105-34-2, 133-134 cm; Kimmeridgian (?); $\times 40$. 
Plate ,
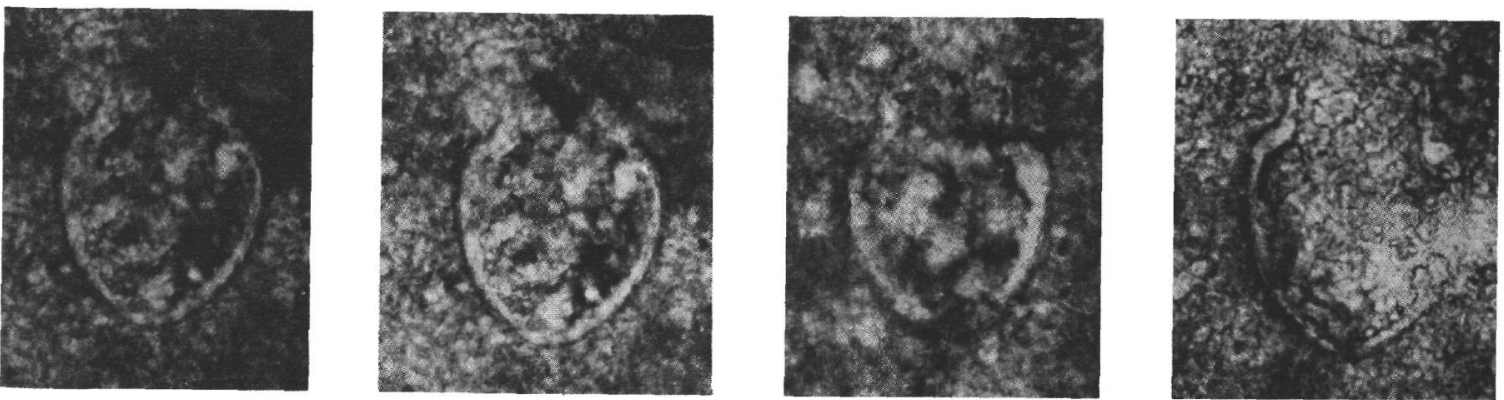

2
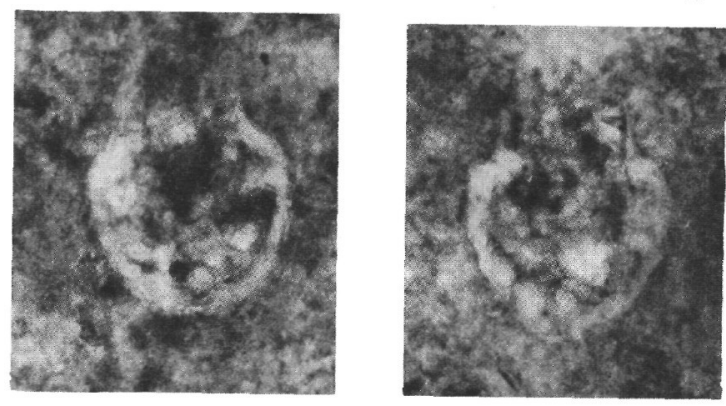

6

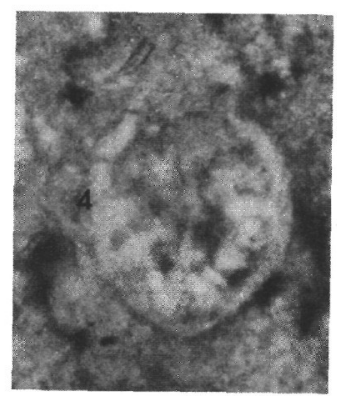

10

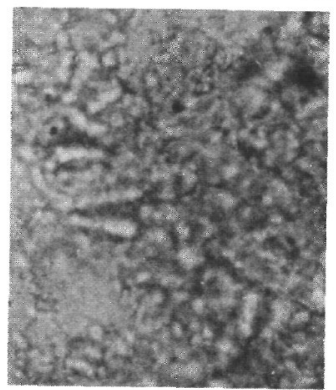

14

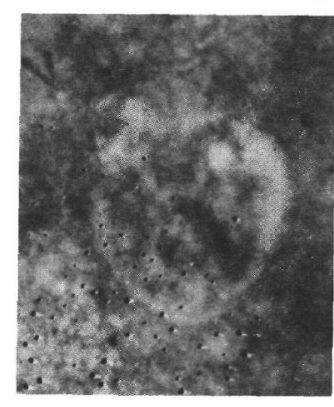

7

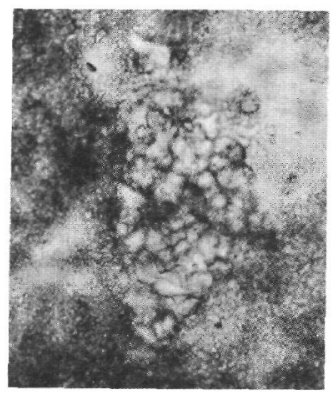

11

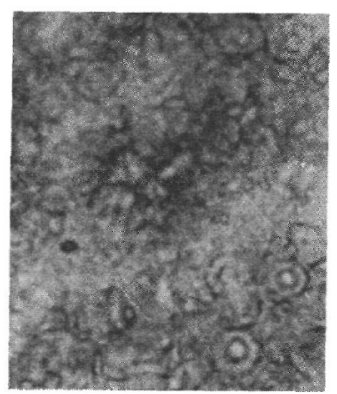

15

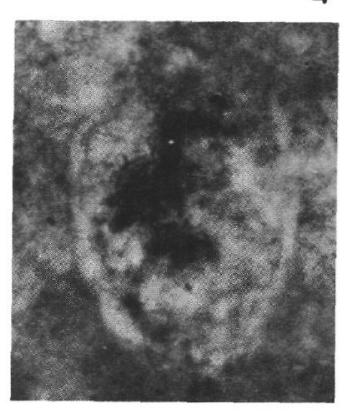

8

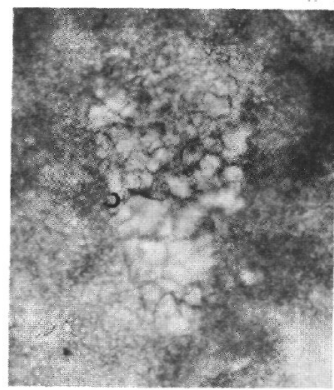

12

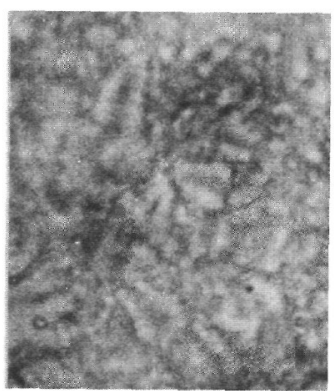

16
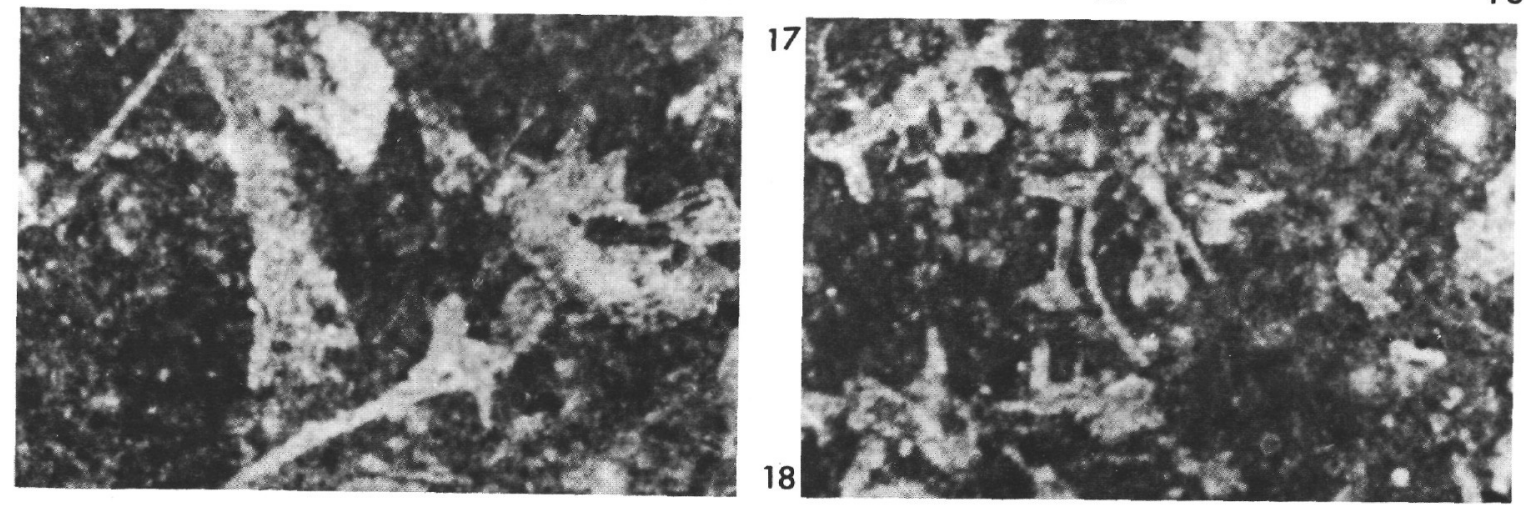